\title{
CONSTITUTIONAL COURT IN ALBANIA, THE DEVELOPMENT OF ITS JURISPRUDENCE TO GUARANTEE THE PRINCIPLE OF CONSTITUTIONALITY
}

DOI: 10.47743/rdc-2016-1-0005

Prof. Asoc. Dr. Migena LESKOVIKU Vice-Dean of Law Faculty \& Head of Public Law Department, Law Faculty, European University of Tirana, Albania

\section{Abstract}

In this paper, have been treated some historical aspect about the establishment of the Constitutional Court, based on the Law no. 7191 of 29 April 1991 on the principle constitutional provisions. The Parliament adopted a new law - the Law no. 8577 of 10 February 2000 on the organization and functioning of the Constitutional Court of the Republic of Albania. During the activity of the Constitutional Court since its establishment in 1992, it has handled different kind of cases based on its competences, creating a rich and bold jurisprudence. An important place in this paper takes the Constitutional control exercised by Albanian Constitutional Court. The paper treats the evolution of jurisprudence of the Constitutional Court in Albania, to guarantee the principles of the constitutionality.

Keywords: Constitution; the Constitutional Court; Constitutional control; principle

\section{Historical background}

The democratic changes that took place in the early 90's marked a radical turn in the history of the Albanian state and its institutions. Democratic orientation of Albania sought carrying a deep institutional reform, which should open the way for democratic transformations, democratic governance based on the rule of law principle and respect for human rights. The basic principles that guided these democratic changes were announced initially in the Law no. 7191 of 29 April 1991 on the principle constitutional provisions, amended a year after its enforcement ${ }^{1}$.

The abovementioned Law consisted of three Constitutional pillars. Thus, the First Law declared the form of government; a democratic parliamentary regime was

\footnotetext{
1 Law no. 7561 of 29 April 1992 on some amendments of the Law no. 7491 of 29 April 1991 on Principal Constitutional Provisions.
} 


\section{Migena LESKOVIKU}

established as well as the principle of separation of powers and political pluralism was introduced. Law II recognized for the first time in Albania the creation of the Constitutional Court as a constitutional control body. Law III recognized an expanded catalog of fundamental rights and freedoms of citizens.

The reforms will continue and deepen further in the context of the installation of a democratic government and the rule of law. They will take other broad dimensions in terms of integration into regional and international structures, with the ratification of a number of international instruments and the start of EU accession processes. Challenges have been and are still big, but it is important that Albania is determined to continue reforms to join the EU.

The existence of constitutional and legal framework in the country is only a necessary premise of the rule of law. Equally important is the functioning of various mechanisms to control the implementation of the constitutional norms, and especially the establishment of a crop of new mentality to public officials but also to the citizens, expressed in the need to implement these norms and the reaction with democratic means against any violations and through the mechanisms of justice ${ }^{2}$.

The Constitutional Court was conceived as one of the most important institutions for guaranteeing the new constitutional order that was installed in Albania. Since the beginning this institution was considered as the highest authority that guarantees respect for the Constitution and makes final interpretations of it. Constitutional Law no. 7561 of 29 April 1992 on some additions and amendments to Law no. 7491 of 29 April 1991 on the principle constitutional provisions that was the ground for the establishment of the Constitutional Court, was followed by the issuance of other acts to regulate its activity. In July 1998 the Albanian Parliament adopted the Law no. 8373 on the organization and functioning of the Constitutional Court of the Republic of Albania, which created a legal basis for the activity of the Constitutional Court.

While in March 1993, Albanian parliament passed the law on "Human rights and fundamental freedoms" and it was added as an integral part of the Law on the principle Constitutional Provisions. This law, for the time, was seen as appropriate one responding to the required concepts and level of human rights as foreseen by various international documents ${ }^{3}$.

The law on constitutional court defined its structure, functions and competencies. The formula of judges' appointments was considered somewhat problematic for the time, as 5 members were elected by the Parliament and the other 4 appointed by the President of the Republic, including the Head of this court. Considering the fact that at the time, the majority of the Albanian Parliament as well as the President of the Republic were part of the same political party, it gave the impression that the first

\footnotetext{
2 L. Omari, Shteti i së drejtës, botimi i katërt, Shtëpia Botuese 'Elena Gjika', Tiranë, 2012, pp. 59-60.

${ }^{3}$ Kushtetuta e re shqiptare, sfida e së ardhmes euroatlantike të Shqipërisë, mundësuar nga Instituti i Studimeve Bashkëkohore Ballkanike, Shtëpia Botuese 'Luarasi', Tiranë, 2002, pp. 20-22.
} 
Constitutional Court was a product of a political scheme already shaped ${ }^{4}$. Thus, as some authors opinioned, the first Constitutional Court could be considered as a "shy guardian" of the constitutional provisions ${ }^{5}$. Nevertheless, the establishment of the Constitutional Court for the first time in the history of the modern Albanian state was a big step forward to be commended and despite the problems deriving from its first organic law, it was a novelty in the Albanian institutional reality ${ }^{6}$. Despite such controversies, it is praised for some delicate decisions for the time, i.e. when the Court declared the unconstitutionality of some laws approved by the parliament such as the law on the fixed criminal punishments, or when deciding on the cases dealing with due process of law etc. It is appraised for defining rules and principles of (constitutional) justice unknown before in the Albanian judiciary system.

Efforts continued and finally, the new Constitution was promulgated and came into force on November 28, 1998. The new constitution created the opportunity for a better understanding of the political system in Albania and the role of its actors. Albania was declared a parliamentary republic, conveying the main principles of parliamentarianism and thus establishing and institutionalizing the set of key principles of governance ${ }^{7}$.

In the process of drafting the new Constitution, in addition to domestic experience, the experience of other countries was considered as well, particularly the models of parliamentary republics, such as Germany, Italy etc. or even some former socialist countries that faced similar problems with those of our country. The Constitution, which was considered by the competent international bodies as a document in full compliance with European democratic standards, paved the way for the normalization of life in the country, development of democracy and the rule of law in Albania.

In Albania's new Constitution, the Constitutional Court again took an important institutional position. It also brought about changes in the appointment of its members, powers/competences and subjects that could initiate a motion to the Constitutional Court that obviously improved its organization and competences. Consequently, the Parliament adopted a new law - the Law no. 8577 of 10 February 2000 on the organization and functioning of the Constitutional Court of the Republic of Albania, which abolished the previous one. This new law was drafted with the assistance of the Venice Commission (otherwise known as the Commission "Democracy through Law") and it regulates issues such as the application, preliminary examination, trial

\footnotetext{
${ }^{4}$ K. Traja, Drejtësia kushtetuese, Shtëpia Botuese 'Luarasi', Tiranë, 2000, pp. 245-246.

5 Ibidem.

${ }^{6}$ The basic constitutional model for designing the Albanian constitutional court at that time was considered the Italian model and the German one at some extent. On the discussions about the constitutional court model to be chosen when the new Constitution was drafting see also: "Debati Kushtetues (diskutimet në komisionin parlamentar për hartimin e projektkushtetutës), Vëllimi 2, OSCE Presence in Albania, Tiranë, 2006, pp. 1-6.

7 The Constitution stipulates in its Article 7, that the system of government in the Republic of Albania is based on the separation and balancing of legislative, executive and judiciary powers. Thus, legislative power belongs to the Assembly, the Executive to the Council of Ministers and judicial power is exercised by courts at the national level with the High Court at the top of the judiciary.
} 
procedures, adjudication, status and mandate of the constitutional judges, decisions and effects etc.

During the activity of the Constitutional Court since its establishment in 1992, it has handled different kind of cases based on its competences, creating a rich and bold jurisprudence over the years, as it has been obvious the progressive effort to appropriately protect the constitutional principles and values.

\section{Constitutional control exercised by Albanian Constitutional Court}

\section{(in view of the judicial review approach)}

Without claiming this paper is exhaustive regarding the constitutional control, as there are a lot of questions to be discussed, I shall only focus on some issues on the competences of Albanian Constitutional Court and its implications in respect of the judicial review approach.

Constitutional justice implies a variety of institutions entitled to protect the legal order of a state, thus considering the Constitutional Court as guarantor of the Constitution - that is an organ that is entitled to protect the Constitution from the eventual violations of the other state bodies. This trend to review the activity of the lawmaker has turned out to be a distinctive feature for all democratic regimes, respecting at the same time, the sovereignty of legislator. Therefore, the role of the Constitutional Court has increased significantly particularly in countries, that emerged from the totalitarian regimes. The requisite to protect the Constitution from the abuses of legislative and executive bodies during its implementation has derived from the principle of rule of law and has been related to the legality of the state power - the exercise of all the functions only in conformity with the law.

The Constitutional Court is not part of the judicial power; and in virtue of para. 1 of Article 124 of the Albanian Constitution, the Constitutional Court provides the final interpretation of the Constitution. The presented application should specify which of the constitutional provision or part of the provision is to be interpreted. As for the effects, the decision of the Constitutional Court, which provides for the interpretation of the Constitution, is retroactive . $^{\text {. }}$

There are some other cases of retroactivity effects or ex tunc effect of a decision issued by the Constitutional Court, such as: when it concerns a criminal sentencing and such a decision is under execution, if directly related with the implementation of the abrogated law or normative act; when it concerns a case under review by the courts, unless their decisions are final; of effects of unimplemented law or normative act ${ }^{9}$.

\footnotetext{
${ }^{8}$ Article 79 of the Law no. 8577 of 10 February 2000 on the organization and functioning of the Constitutional Court of the Republic of Albania.

${ }^{9}$ Article 76/2 of Law no. 8577 of 10 February 2000 on the organization and functioning of the Constitutional Court of the Republic of Albania.
} 
According to the Article 131 of the Constitution, the Constitutional Court decides on:

a) compatibility of the law with the Constitution or with international agreements as provided in Article 122;

b) compatibility of international agreements with the Constitution, prior to their ratification;

c) compatibility of normative acts of the central and local bodies with the Constitution and international agreements;

c) conflicts of competencies between powers, as well as between central government and local government;

d) Constitutionality of the parties and other political organizations, as well as their activity, according to article 9 of the Constitution;

dh) dismissal from duty of the President of the Republic and verification of the impossibility to exercise his function;

e) issues relating to the election and incompatibility in exercising the function of the President of the Republic and of the deputies, as well as of their election;

ë) constitutionality of the referendum and verification of its results;

f) final adjudication of the individuals' complaints for the violation of their constitutional rights to due process of law, after all legal means for their protection have been exhausted.

Constitutional Court is responsible to review the normative acts in compliance with the constitutional provisions, and if the case, declares the unconstitutionality of these acts. Due to the nature of cases judged by the Constitutional Court, it has often been the target of political criticisms. These clashes are inevitable considering the subject matter of Constitutional Court - judicial review of the constitutionality of the acts issued by the three powers (specially the acts issued by legislative and executive powers). Moreover, the Constitutional Court has the duty to oversee whether the political power has been exercised under the limits recognized by law. These limitations should not be exceeded otherwise the whole system of legal order and state authority will not be respected.

Considering its competences as cited above in the Article 131 the Constitutional Court exercises both a priori and a posteriori review. It exercises a priori review only in two cases as foreseen by Albanian Constitution - that is when it reviews the compatibility of international agreements with the Constitution before their ratification, as well as the constitutionality of cases put forward for referendum ${ }^{10}$. In all other cases it exercises a posteriori review.

As mentioned before, according to the constitutional provisions, Constitutional Court has the duty to oversee the applicability of the Constitution by other public

\footnotetext{
${ }_{10}$ Regarding the constitutionality of the referendum as foreseen in article 131/ë, the a priori control is exercised for the question a referendum is to be organized, whereas the verification of the results of a referendum the control exercised by Constitutional Court is a posteriori. See also L. Omari, Shteti i së drejtës, botimi i katërt, Shtëpia Botuese 'Elena Gjika', Tiranë, 2012, p. 270.
} 
authorities. The Constitutional Court is the responsible authority entitled to perform the judicial review of the normative acts enacted by other state bodies, focusing on their compatibility with the Constitution. The Constitutional Court reviews the compatibility of laws and normative acts of central and local bodies with the Constitution or international agreements ${ }^{11}$. The Constitutional Court has the competence to review the compatibility of international agreements with the Constitution before their ratification, thus being one of the two cases of exercising a priori control. When Constitutional Court has abrogated a law or normative act as incompatible with the Constitution or International Agreements, its legal effects starts from the date of its enforcement.

Another interesting topic to be discussed regards the individual complaints. In view of article 131/f, cited above, article 134/g of the Albanian Constitution states that the Constitutional Court initiates a proceeding on the request of individuals, but the request must concern only issues related to their proper interests. The Constitutional Court decides on "the final adjudication of the complaints of individuals for the violation of their constitutional rights to due process of law, after all legal remedies for the protection of those rights have been exhausted"12.

Article 42 of Albanian Constitution stipulates:

"1. The liberty, property and rights recognized in the Constitution and by the law may not be infringed without due process. 2. Everyone, to protect his constitutional and legal rights, freedoms, and interests, or in the case of charges against him, has the right to a fair and public trial, within a reasonable time, by an independent and impartial court specified by law".

From the content of this provision it is clear that the constitutional jurisdiction is limited to individuals only in terms of protection of their constitutional rights to due process of law. The understanding of this provision becomes difficult, since it has not been given a (constitutional) definitional provision of the fair trial. Unlike the article 6 of European Convention of Human Rights, the elements of the due process of law are scattered in several provisions of the Albanian Constitution, namely its articles 28-44. However, following the components of due process of law as foreseen in the article 6 ECHR as well as the case-law of the European Court of Human Rights, the Albanian Constitutional Court has managed to establish a rich and solid jurisprudence. The problems of the fair trial are mainly related to judicial procedures. The individual's right of the fair trial includes several rights, legal and constitutional guarantees. Violation of the constitutional guarantees provided for in the chapter of personal rights and freedoms has been considered by the jurisprudence of the Constitutional Court as constitutive part of the unfair trial ${ }^{13}$.

\footnotetext{
${ }^{11}$ Article 122/2 of the Albanian Constitution states: "An international agreement ratified by law constitutes part of domestic legal system and has priority over the laws of the country that are incompatible with it".

${ }_{12}$ Article 131/f of the Albanian Constitution, as cited above.

${ }^{13}$ Kushtetuta e re shqiptare, sfida e së ardhmes euroatlantike të Shqipërisë), mundësuar nga Instituti i Studimeve Bashkëkohore Ballkanike, Shtëpia Botuese 'Luarasi', Tiranë, 2002, pp. 80-83.
} 
Individuals can not complain on matters not related to due process and this constitutional barrier does not guarantee the effectiveness of Constitutional Court decision. In some cases the Constitutional Court was considered an ineffective tool as the ECtHR has decided in several cases, particularly in cases of control over the execution within a reasonable period of final judicial decisions. These problems have highlighted the importance of standard of an effective remedy as provided in Article 13 of the $\mathrm{ECHR}^{14}$.

The direct submission of the individual's application to the Constitutional Court is related to the observance of some formal procedural requirements, which are presented in more details in the organic law on the Constitutional Court. It regulates some important elements such as the way of submitting the application, its time limits that must not exceed two years since the violation has been ascertained, the documents attached to the application, realization of defense by the applicant or through his/her representative etc.

Another interesting issue on the constitutional review regards the incidental control $^{15}$. In the principle method, the constitutional issue is the only and principal question of the process initiated through the exercise of a direct action that can be brought before the Constitutional Court, either by someone through an action popularis or within some locus standi rules or by specific public officials and authorities as specified in Article 134 of the Albanian Constitution ${ }^{16}$. In the incidental control, the constitutional issue is raised before an ordinary court as an incidental question aspect of a process, or the court can raise it ex officio. This court is the one which must refer the constitutional question to the Constitutional Court, the suspension of the decision of the concrete case being necessary until the constitutional issue is resolved ${ }^{17}$. This is the case of Albanian Constitution, as well. Following the Italian constitutional model, Albanian Constitution has provided that when a court of any instance or the respective judge, during the trial considers ex officio or through the request of either party involved that a certain law is unconstitutional and if there is a direct link between the law and the solution of the case at hand, that particular law is not implemented and after suspending the trial the judge delivers the file to the Constitutional Court, which on its side should express itself about the constitutionality of the said law. The decision of the court or of the respective judge should define the provisions of the law they consider incompatible with the said norms or other principles of the Constitution that

\footnotetext{
${ }^{14}$ Case-law Gjyli v. Albania, ECtHR, 2007.

${ }^{15}$ Article 145/2 of the Albanian Constitution.

${ }^{16}$ Article 134 of the Albanian Constitution determines: 1. The Constitutional Court is put into motion on the request of: a) The President of the Republic; b) The Prime Minister; c) Not less than one-fifth of the deputies; c) The Head of the High State Audit; d) Every court according to article 145, paragraph 2 of the Constitution; dh) The People's Advocate; e) Bodies of the local government; ë) Bodies of religious communities; f) Political parties and other organizations; $g$ ) Individuals. 2. The subjects provided for in subparagraphs dh), e), ë), $f$ ) and $g$ ) of the paragraph 1 of this article, could make a request only for issues related with their interests.

17 V.C. Jackson, M. Tushnet, Comparative constitutional Law, $2^{\text {nd }}$ ed., Foundation Press, New York, 2006, p. 491.
}

CONSTITUTIONAL JURISDICTIONS 


\section{Migena LESKOVIKU}

the law has not respected or violated, as well as the reasons they present the application for abrogation ${ }^{18}$.

One of the problems, regards the situation when because of the incidental control, the Constitutional Court declares the unconstitutionality of the law or a certain law provision. Upon the enforcement of such decision of Constitutional Court, a legal vacuum is experienced as the courts have to wait for the adoption of a new law by the legislator. In such case, the courts are obliged to wait until, the legislator make appropriate amendments directly related to the trial and suspend the trial indefinitely until new law provisions are adopted. Such problems are already addressed and hopefully will be part of the changes in the constitutional and justice reform which is under way.

In principle, a decision adopted by a Constitutional Court has general effects so that it applies erga omnes. The Constitutional Court annuls the law or a part of it that is considered to be unconstitutional and their decision has an erga omnes effect. Even when judicial review is sought by incidental control, the decision of the Constitutional Court must be concentrated on aspects regarding law only and not facts. Since the court in this case is not limited to a concrete process or to the parties in which the constitutional question was originally raised, the effects must also be erga omnes.

After voting, the decision of the Constitutional Court is considered valid and cannot be changed. The decision of the Constitutional Court is binding to all and final ${ }^{19}$ and its execution is obligatory. The judge in dissenting opinion enjoys the right to reason his opinion and thus it is attached to and published together with the court decision, as Article 132/2 of Albanian Constitution determines.

When a case is submitted to the Constitutional Court it is important to emphasize the continuity of constitutional jurisprudence. The Constitutional Court cannot annul or change its own decisions, but it can: interpret the decision in case of doubts or disputes concerning its understanding, but never changing its content; complete the decision or correct any possible mistake in calculating or any other evident inaccuracy in it within 2 (two) months from the date of its proclamation.

The need for consistency has a tremendous value. It would not be desirable if the law won't be "alive"; but the development is done in stages, settings and corrections are made progressively. This is stated by the Constitutional Court, which in one of its decisions opinions: "Any change of the Constitutional Court precedents or correction of the official constitutional doctrine cannot be based on random factors; nor can be changed based on its composition".

Ensuring continuity of constitutional jurisprudence is an obligation of the Court, but on the other hand, its jurisprudence can also be subject to its evolution. From this

\footnotetext{
${ }^{18}$ Article 68 of the Law no. 8577 of 10 February 2000 on the organization and functioning of the Constitutional Court of the Republic of Albania.

${ }^{19}$ Article 132 of the Albanian Constitution.
}

CONSTITUTIONAL LAW REVIEW 


\section{Constitutional Court in Albania...}

perspective, there is always the possibility that this jurisprudence, being supplemented by new interpretive conclusions, also be changed. But the Court notes that a change of its practice can be realized if there are compelling reasons that would justify such a necessity, and, only when it is inevitable, objectively necessary, as well as constitutionally grounded and reasoned.

The best example of this approach is illustrated in one of the decisions ${ }^{20}$ of Albanian Constitutional Court stating that:

According to the powers given by Article 124 of the Constitution, the role and function of the Constitutional Court is that through its decisions, constitutional provisions are transformed from abstract-metaphysical, in substantive and concrete, thus guaranteeing constitutional protection to individuals' legal situations.

Due to the extremely concise form the constitutional provisions have, through decisions, that is the interpretation the Court does, it becomes possible for the Constitution to be "alive", which means that the Court is adapted to the evolution of the (constitutional) values in our country, by ensuring that the new values, which were probably not at the attention of the drafters of the Constitution, obtain dignity, recognition and, above all, constitutional protection. Given the fact that constitutional norms become a reality during the interpretation, that is, during the decision making process of the Court, it makes the latter unquestionably a source of law, moreover makes it a primary source of law, considering the Article 4 of the Constitution which provides that the Constitution is the highest law in the Republic of Albania. In this sense, we can say that the Constitutional Court has two fundamental functions: the push-evolutionary one described above, which is often a consequence of the values enshrined in the ECtHR decisions and the fact that the Court can use in support of its reasoning the attitudes European counterparts Courts have held and, in turn, defense-conservative function, guaranteeing immutability of constitutional protection for those values that are seen as essential by the people of the Republic of Albania, whose will is interpreted by the Constitutional Court. Both functions are important and equivalent simultaneously.

\section{Conclusions}

"It is impossible (...) to propose a uniform solution for all possible constitutions: constitutional review will have to be organized according to the specific characteristics of each of them", Kelsen's wise warning was followed by countries establishing systems of constitutional review ${ }^{21}$. Although many countries have followed the European model, each has tailored its system to its own needs, circumstances, political situation and legal

\footnotetext{
${ }^{20}$ Decision no. 20/2011 of the Albanian Constitutional Court.

${ }^{21}$ V.C. Jackson, M. Tushnet, cited paper, p. 478.
}

CONSTITUTIONAL JURISDICTIONS 


\section{Migena LESKOVIKU}

tradition. That is the case of Albanian Constitution as well. As such, Albanian Constitution is very much a living document, as the constitutional judicial review has played a significant role in forming a constitutional reality promoting the fundamental values and principles in order to establish rule of law and democratic governance in the country.

Albanian Constitutional Court is an independent body outside the judiciary. It is independent of all branches of government vested with the fundamental function to interpret and guarantee compliance with the Constitution.

Since its foundation, the Constitutional Court of Albania has been shaped as a pure constitutional institution like its homologues in European countries, developing a vivid and rich jurisprudence. The Constitutional Court has become an independent body which ensures the supremacy of the Constitution. The decisions of the Constitutional Court are binding on all other courts and are not subject to review by any other body. It also has a significant political role, ruling on the constitutionality of political parties and organizations, as well as their activities; verification of the results of referenda and their constitutionality; and election and dismissal of the President of the Republic.

Although Constitutional Court decisions which revoke laws and other normative acts may have political implications as they thwart the political objectives which the acts sought to achieve, the Constitutional Court should not be termed a political court; despite the fact that due to the nature of cases judged by the Constitutional Court, it has often been the target of political criticisms.

The principle of separation and balance of powers is imposed by the Constitution even to the Constitutional Court to control the observance of this principle, as a fundamental component of rule of law. The Constitutional court has reconfirmed that it is not the task of this court to take the role of positive legislator, but to review whether the solution provided for by the legislator is in accordance with the provisions of the Constitution $^{22}$.

The outcome of Constitutional court's decision on unconstitutionality of a normative act within the system of abstract constitutional review is invalidation of that act in respect to all (erga omnes effect). The normative act declared to be unconstitutional ceases to exist. However, there are disputes on the moment when it ceases to exist. There can be no doubt as to the action of law in the future. However, there are some matters to be discussed on the retroactivity and reasonable arguments with the complex issue how to deal with all consequences that followed from the moment when the law was enacted till the moment when the constitutional court's decision has been announced.

Over the years, the Constitutional Court of Albania has expanded the concept of individual rights and the right to appeal in accordance with the ECHR standards. Also,

22 The Decision no. 12/2010 of the Albanian Constitutional Court.

CONSTITUTIONAL LAW REVIEW 


\section{Constitutional Court in Albania...}

the Constitutional Court has extended individual spaces, interpreting maximum legitimacy in favor of access to court. Individual may apply to the court not only when all the other means are exhausted, but even when tracking the appeal procedures would result in excessive length of infringement or a further exacerbation of the situation ${ }^{23}$.

The need for consistency has a tremendous value when it comes to the jurisprudence developed by our Constitutional Court. It is an obligation of the Court, but on the other hand, its jurisprudence can also be subject to its evolution if constitutionally grounded and reasoned.

${ }^{23}$ Ibidem. 